\title{
Downscaling Climate Projections over La Plata Basin
}

\author{
Caroline Mourão1,2*, Sin Chan Chou' ${ }^{1}$ José Marengo² \\ ${ }^{1}$ National Institute for Space Research, Cachoeira Paulista, Brazil \\ ${ }^{2}$ National Center for Natural Disaster Monitoring and Early Warning, São José dos Campos, Brazil \\ Email: "caroline.mourao@cemaden.gov.br
}

Received 15 October 2015; accepted 28 December 2015; published 31 December 2015

Copyright (C) 2016 by authors and Scientific Research Publishing Inc.

This work is licensed under the Creative Commons Attribution International License (CC BY). http://creativecommons.org/licenses/by/4.0/

(c) (i) Open Access

\begin{abstract}
Regional Climate Models are important tools, which are increasingly being used in studies of impacts and adaptation to climate change at local scale. The goal of this work is to assess the climate change over the La Plata Basin, using the Eta Regional model with a resolution of $10 \mathrm{~km}$. Initial and boundary conditions used by the model are provided by the Eta-20 $\mathrm{km}$ model and the HadGEM2ES Global model. The RCP 4.5 scenario was used for simulations of the future climate. The evaluation of the present climate (1961-1990) shows that the model represents well the spatial and temporal distribution of precipitation and temperature in the region. The model underestimates precipitation over large areas in summer, and overestimates in Southern Brazil in winter. Simulated temperature shows a good correlation with CRU data, with bias less than $1^{\circ} \mathrm{C}$. The bias of temperature and precipitation in this simulation setup for the La Plata Basin is substantially reduced in comparison with previous literature using regional models. The climatic projections are shown in timeslices: 2011-2040, 2041-2070, and 2071-2099. In the three timeslices, the simulation project has a trend for an increase in precipitation during summer in Argentina, Uruguay, and southernmost Brazil. This increase is only projected in Southern Brazil during winter. The negative anomaly of precipitation appears in a large portion of the model domain during summer and is limited to some states in Southeast and Central-West Brazil in winter. The area with largest warming is projected in the northern portion of the domain. The projected increase in temperature reaches about $4^{\circ} \mathrm{C}$ in 2071-2099.
\end{abstract}

\section{Keywords}

Regional Climate Model, Climate Downscaling, Climate Change Assessment, La Plata Basin

\footnotetext{
"Corresponding author.
} 


\section{Introduction}

The study region of this work is the La Plata Basin (LPB), which covers an area near 3,200,000 $\mathrm{km}^{2}$ (Figure 1). In terms of its geographic extension, this basin is the fifth largest in the world, the second largest in South America after the Amazon Basin. The basin is divided in three large sub-basins, corresponding to the Parana, Paraguay, and Uruguay Rivers. The LPB covers five countries, with approximately $46 \%$ of its area in Brazil, $30 \%$ in Argentina, $13 \%$ in Paraguay, $7 \%$ in Bolivia and $4 \%$ in Uruguay.

The agricultural sector of this region has expanded in recent years, due to worldwide demand for crops and biofuels. Additionally, a 20\% - 30\% increase in mean annual precipitation during the last 30 years has favored an expansion of the agricultural frontier, mainly of wheat and soy crops. However, global warming projections up to the end of the 21st century show risks of crop collapse due to vulnerability to great climatic fluctuations, mainly prolonged drought periods and an increase in the frequency of intense rains [1]-[4].

In the context of impacts and adaptation (e.g. agriculture, water resources management, health) integrated evaluation strategies are gaining popularity, in which regional climate change projections provide important information for decision making systems, with the aim of reducing vulnerability. According to Marengo et al. [1], a relatively small number of studies have been made on impacts and vulnerability in Brazil using projections of regional-scale climate change scenarios. However, they do not leave any margin for doubt: Brazil will not be spared by climate change [1].

In South America, dynamic downscaling of climate change scenarios has been recently made available for various emissions scenarios and periods up to the end of the 21st century, using different regional models driven by various global climate models [1] [5]-[8].

According to Solman [9], various studies of South America have been made in recent years, which have demonstrated that regional-scale climate simulations are affected by various sources of uncertainty. One of these stems from the land-surface schemes. An increase in spatial resolution, among other factors, can contribute to a better representation of the surface by, for example, offering a better representation of topography and landsurface cover.

The objective of this work is to assess the climate change in the La Plata Basin, using simulations from the regional climate model Eta-10 km with initial and boundary conditions from the Eta-20 km and HadGEM2-ES (UK Met Office Hadley Centre Global Environmental Model, version 2, with Earth System components) models, using the RCP 4.5 scenario [10].

In this work, we analyze the spatial fields at the seasonal scale, and the annual cycle of precipitation and nearsurface temperature of the Eta model. Prior to use the model projections, the simulations are evaluated in the

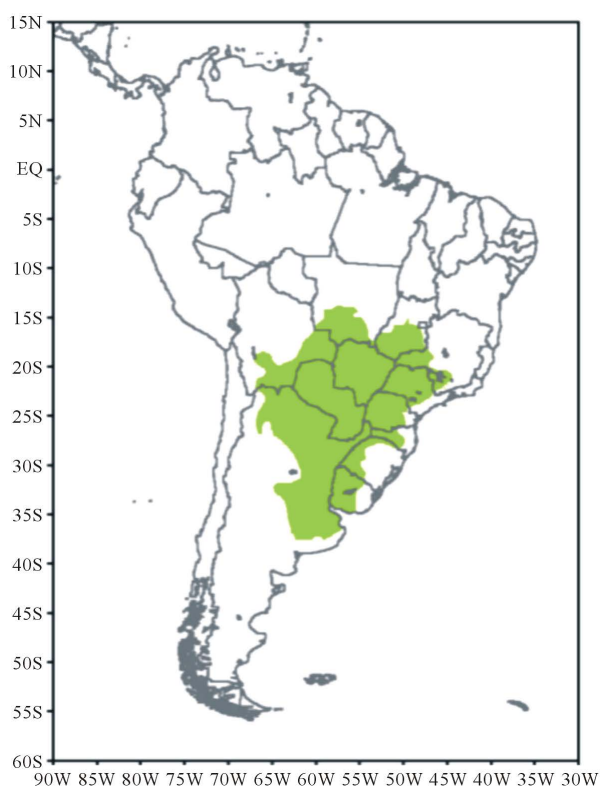

Figure 1. La Plata Basin area (in green). 
present climate period using CRU (Climatic Research Unit, [11]) data as observations. The analysis of changes in temperature and precipitation, relative to present climate, is done in three timeslices: 2011-2040, 2041-2070, and 2071-2099.

\section{Data and Methodology}

The Eta model was used for simulations of the periods 1960-2005, 2006-2040, 2040-2070 and 2070-2099. The analyzed periods are 1961-1990 (present climate), 2011-2040, 2041-2070 and 2071-2099 (future climate). A brief description of the principal characteristics and configurations of the regional model and of the global model used for boundary conditions, as well as an explanation of the $\mathrm{CO}_{2}$ emissions scenario used follows.

\subsection{HadGEM2-ES}

The HadGEM2-ES [12] model consists of an Atmospheric Global Circulation Model (AGCM) with a N96 horizontal resolution (approximately $1.875^{\circ} \times 1.250^{\circ}$ longitude by latitude) and 38 vertical levels, and an oceanic model (OGCM) with a horizontal resolution of 1 degree (elevated to 1/3 degree at the equator) and 40 vertical levels.

The earth system components include the terrestrial and oceanic carbon cycles and atmospheric chemistry. Vegetation and the terrestrial carbon cycle are represented by the TRIFFID (Top-down Representation of Interactive Foliage Including Dynamics, [13]) dynamic global vegetation model.

Oceanic biology and chemistry are represented by the Diat-HadOCC model. Tropospheric chemistry is represented by the UKCA (United Kingdom Chemistry and Aerosols) model and also includes new aerosol species (organic carbon and dust).

HadGEM2-ES uses a hypothetical calendar, in which each year is composed of 12 months with 30 days each, in other words 360 days/year. The variables used as initial and boundary conditions in the Eta-20 km model are specific humidity, temperature, mean sea-level pressure and horizontal wind.

\subsection{Eta}

The Eta regional model was developed at the Belgrade University [14] and used operationally at NCEP [15]. Since 1997 it is used by INPE for weather forecasts [16]. This model has been used since 2002 for operational seasonal climate forecasts [17]. A version of the model was developed for climate change studies [5] [6] [18], and its results were used in 2010 for Brazilian Second National Communication to the UNFCCC (United Nations Framework Convention of Climate Change [19]). This work uses the version of the model developed for the Brazilian Third National Communication [7] [20].

Radiative fluxes are treated by Fels-Schwarzkopf scheme [21] for long waves, and Lacis-Hansen scheme [22] for short waves. $\mathrm{CO}_{2}$ follows the emission scenarios, and is updated every 3 years. The two radiative schemes are called every hour of model integration. The cumulus convection scheme used is that developed by Betts and Miller [23] and modified by Janjic [24]. Cloud microphysics follows the Zhao et al. [25] scheme. The land-surface scheme used is that of Noah [26].

\section{Simulation Configuration}

The model horizontal grid is the Arakawa E grid, configured at about $10 \mathrm{~km}$ horizontal resolution. This work uses 38 vertical levels. Initial and boundary conditions are given by the Eta-20 km at each 6 hours (specific humidity, temperature, mean sea-level pressure, surface pressure and horizontal wind), as well as the boundary conditions from the HadGEM2-ES model. The Sea Surface Temperature (SST), provided by HadGEM2-ES, was interpolated linearly from monthly mean values, whereas the Eta model updated the equivalent $\mathrm{CO}_{2}$, according to RCP 4.5 scenario, at every 3 year. The initial conditions of albedo are from climatology. Soil water follows the scheme of Chen et al. [27] which uses four soil levels and a map of 13 vegetation cover types and 9 soil types. The Eta model calendar was modified in order to follow the HadGEM2-ES model's calendar and, consequently, synchronize the seasonal cycles of the models.

\subsection{Greenhouse Gas Emissions Scenarios}

The future emissions of greenhouse gasses (GHG) are the result of complex dynamic systems, determined by 
driving forces such as demographic growth, socio-economic development and technological advancements. Emissions scenarios represent various development pathways which may unfold in the future. The scenarios assist in analyses of climate change, including climate modeling and evaluation of impacts, adaptation and mitigation. According to the AR5 [28] assessment report, in previous reports (TAR and AR4), SRES (Special Report on Emission Scenarios [29]) emissions scenarios were used in order to explore the uncertainty of the anthropogenic contribution to climate change in the future climate. More recent research has used RCPs (Representative Concentration Pathways) [30], which are new scenarios that specify concentrations and corresponding emissions, but which are not directly based on socio-economic evolution, unlike the SRES scenarios. The RCP scenarios are based on a different approach and include short-lived gasses more consistent with land use changes. They are not necessarily more capable of representing the future evolution of GHG concentrations than the SRES scenarios.

The four RCP scenarios are identified by their peak or stabilization value of the Radiative Forcing (RF) in the 21st century. The RCP 4.5 [10] intermediate scenario, defined as such for having a peak $4.5 \mathrm{~W} \cdot \mathrm{m}^{-2} \mathrm{RF}$ value around 2100, was the emissions scenario chosen for this work. The model uses the $\mathrm{CO}_{2}$-equivalent concentrations from the RCP 4.5 scenario.

\section{Results and Discussion}

The precipitation and air temperature fields simulated by the Eta regional model are analyzed during the periods of summer (DJF) and winter (JJA). The analysis of present climate (1961-1990) is done based on the CRU data set, while the analysis of future climate (2011-2099) is based on the difference between the future climate and the present climate integrations.

\subsection{Analysis of Present Climate (1961-1990)}

\subsubsection{Precipitation}

The principal characteristic of the precipitation regime in most of South America (SA), is a well-defined annual cycle, with a maximum in summer (DJF) and a minimum during the winter (JJA) [31]. This cycle is associated to the annual variation of atmospheric circulation over SA and adjacent areas [32], strongly related with seasonal solar heating. Climatologically, the spatial and temporal distribution simulated by the Eta model is in agreement with patterns found in scientific literature and with observational data used in this study (Figure 2).

As seen in Figure 2, the Eta model generally captures well the spatial distribution of precipitation during summer (DJF). However, some differences between the model and observations are evident. The model underestimates rainfall along the climatological position of the South Atlantic Convergence Zone (SACZ). This error in the representation of the SACZ band was identified in Solman et al. [33] and Chou et al. [20]. This negative bias may be related to the difficulty of models in representing some components of the hydrological cycle, such as the vegetation cover, soil moisture, surface fluxes, and the parameterization of convection.

Although it overestimates precipitation during winter (JJA), the model generally shows a behavior similar to observations. During this period, in the simulation, it is possible to notice the reduction in precipitation over central Brazil and increase of rains over the Southern region of Brazil, Paraguay, Uruguay, and southern Chile, because of frontal systems passages typical of this period of the year [34].

In the works of Solman et al. [33] and Chou et al. [20], a negative bias in precipitation was identified in northern Argentina and southern Brazil. However, this bias is not found in this simulation using Eta-10 km.

Figure 3 shows that there is an underestimation of precipitation in LPB up to $1.5 \mathrm{~mm} /$ day during summer, and an overestimation of the same magnitude during winter. In relation to CRU, it is noteworthy that although the Eta model presents a similar seasonal cycle, with a reduction in precipitation during winter, the amplitude of this cycle is smaller in the simulations than in observations.

\subsubsection{Temperature}

Figure 4 shows seasonal-mean temperature values. The model represents well the spatial pattern of temperature. Temperature varies seasonally, in accordance with incoming solar radiation at the surface. The simulations show the seasonal variation in temperature, with higher values in summer (DJF) and lower values in winter (JJA). It is also possible to notice simulations of incursions of cold air from southern SA during winter (JJA), which is the period during which the South Atlantic Subtropical High (SASH) is displaced northward, favoring the frontal 


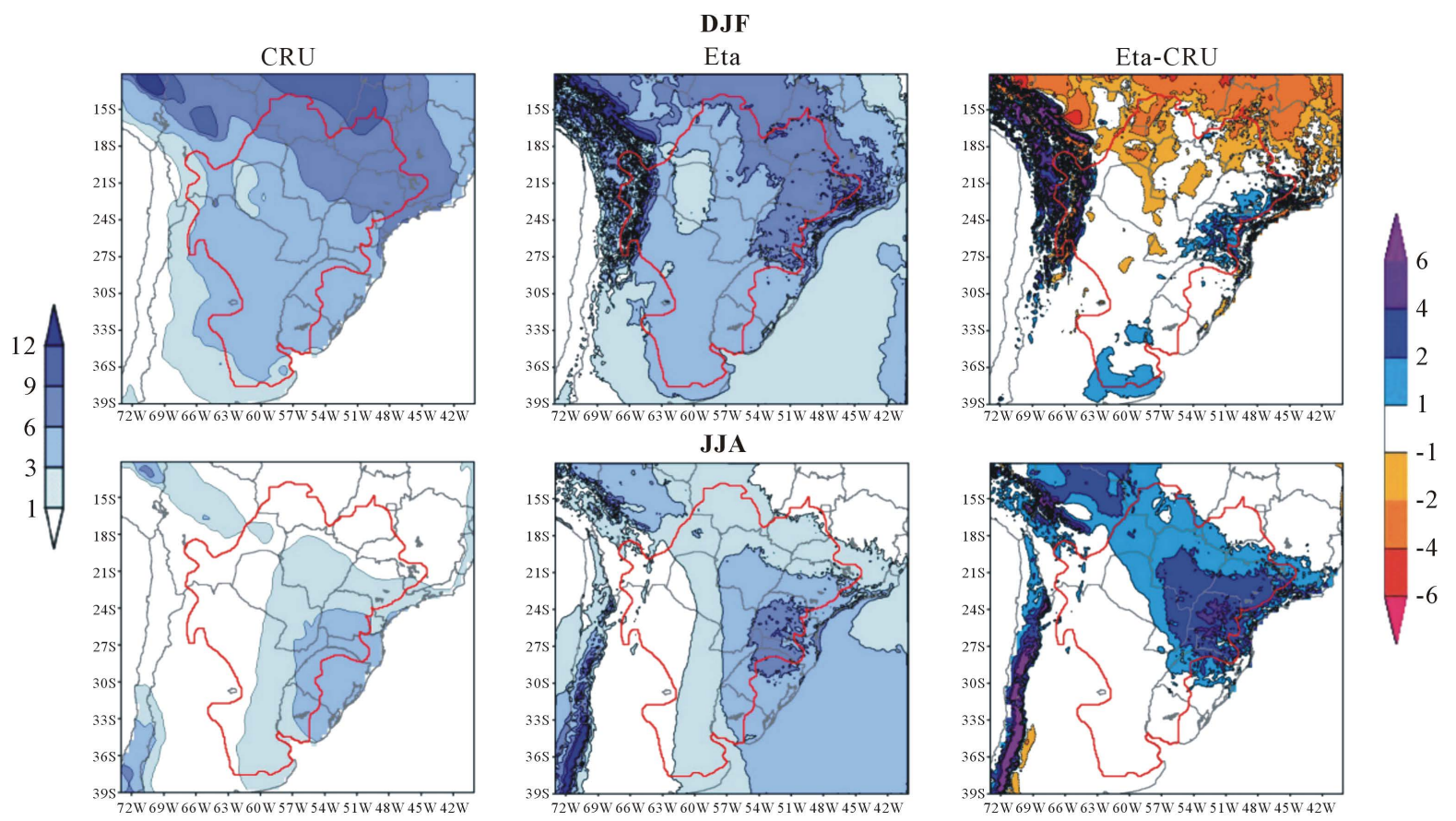

Figure 2. Seasonal mean of precipitation (mm/day) for the period 1961-1990 for summer (DJF) and winter (JJA). CRU observations; Eta-10 km model; and precipitation bias (mm/day) of the Eta simulation in relation to CRU. The La Plata Basin is contoured in red.

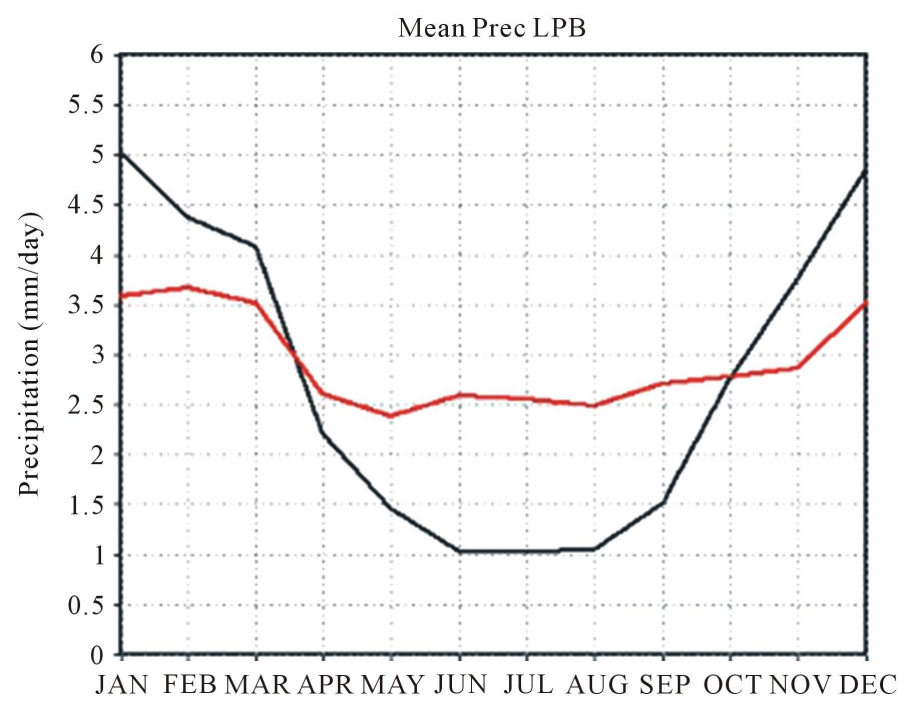

Figure 3. Annual cycle of precipitation (mm/day) in the La Plata Basin (green area shown in Figure 1). The black curve refers to CRU data and the red curve, the Eta-10 km model.

systems to reach this region.

Although there is agreement between the temperature simulated by the Eta and CRU observations, the model tends to show high negative bias during both seasons, in the west coast of the model domain, where the Andes is located. This result has also been found by various authors, which consider that this bias should be evaluated with caution, due to the scarcity of observational data in areas of complex topography [20] [33] [35].

The overestimation of temperature in LPB, mainly during summer, which is found in Chou et al. [18], Solman et al. [33] and Chou et al. [20], is not seen in this simulation.

A comparison with observed annual temperature cycle indicates that on average the Eta model overestimates 
temperature during the first semester of the year and underestimates from August in the La Plata Basin. In general the model represents well the annual cycle of temperature, as well as its amplitude. The difference between simulated and observed temperature does not exceed $1^{\circ} \mathrm{C}$ (Figure 5).

\subsection{Future Climate Projections}

\subsubsection{Precipitation}

Figure 6 shows the average difference of seasonal precipitation for the periods 2011-2040, 2041-2070 and 2071-2099, in relation to the 1961-1990 period (this difference we hereby name anomaly). In this figure, it is
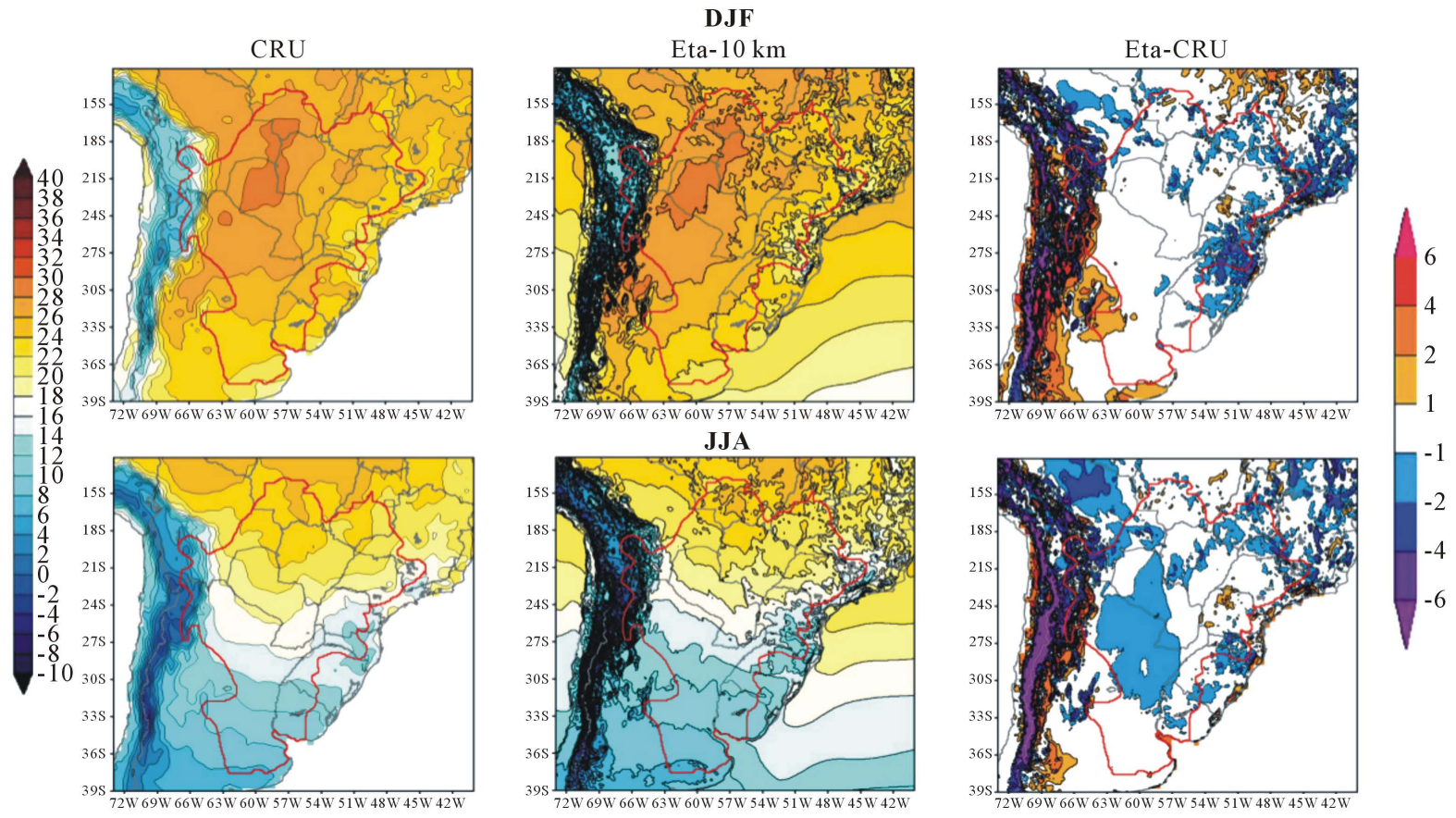

Figure 4. Seasonal mean temperature near the surface $\left({ }^{\circ} \mathrm{C}\right.$ ) during the period 1961-1990 for summer (DJF) and winter (JJA). CRU observations; Eta-10 km model; and temperature bias $\left({ }^{\circ} \mathrm{C}\right)$ of the Eta simulation in relation to CRU. The La Plata Basin is contoured in red.

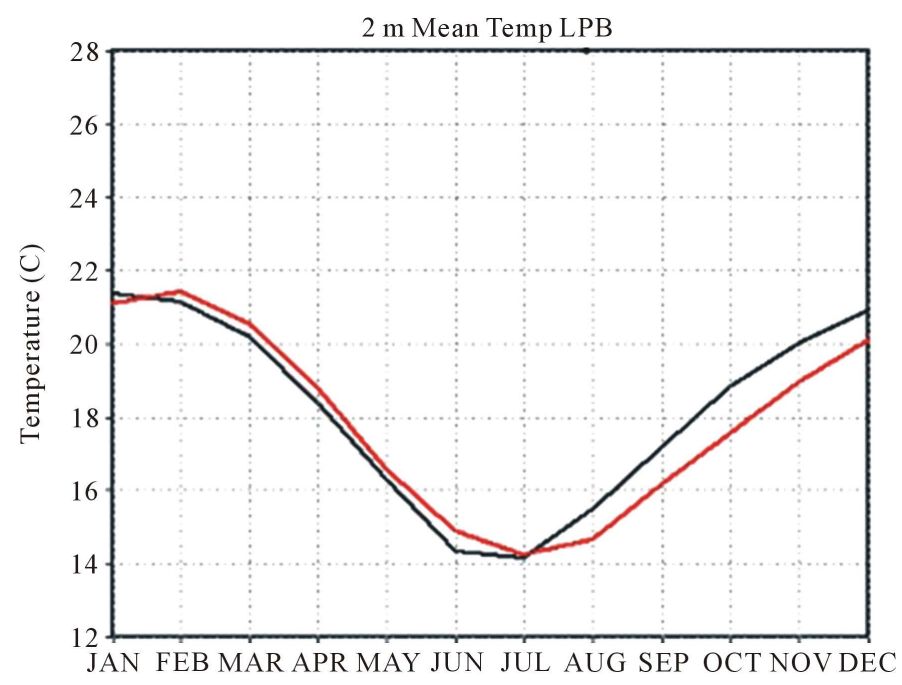

Figure 5. Annual cycle of Temperature at $2 \mathrm{~m}\left({ }^{\circ} \mathrm{C}\right)$ in the La Plata Basin (green area shown in Figure 1). The black curve represents CRU data and the red curve the Eta-10 km model. 
2011-2040
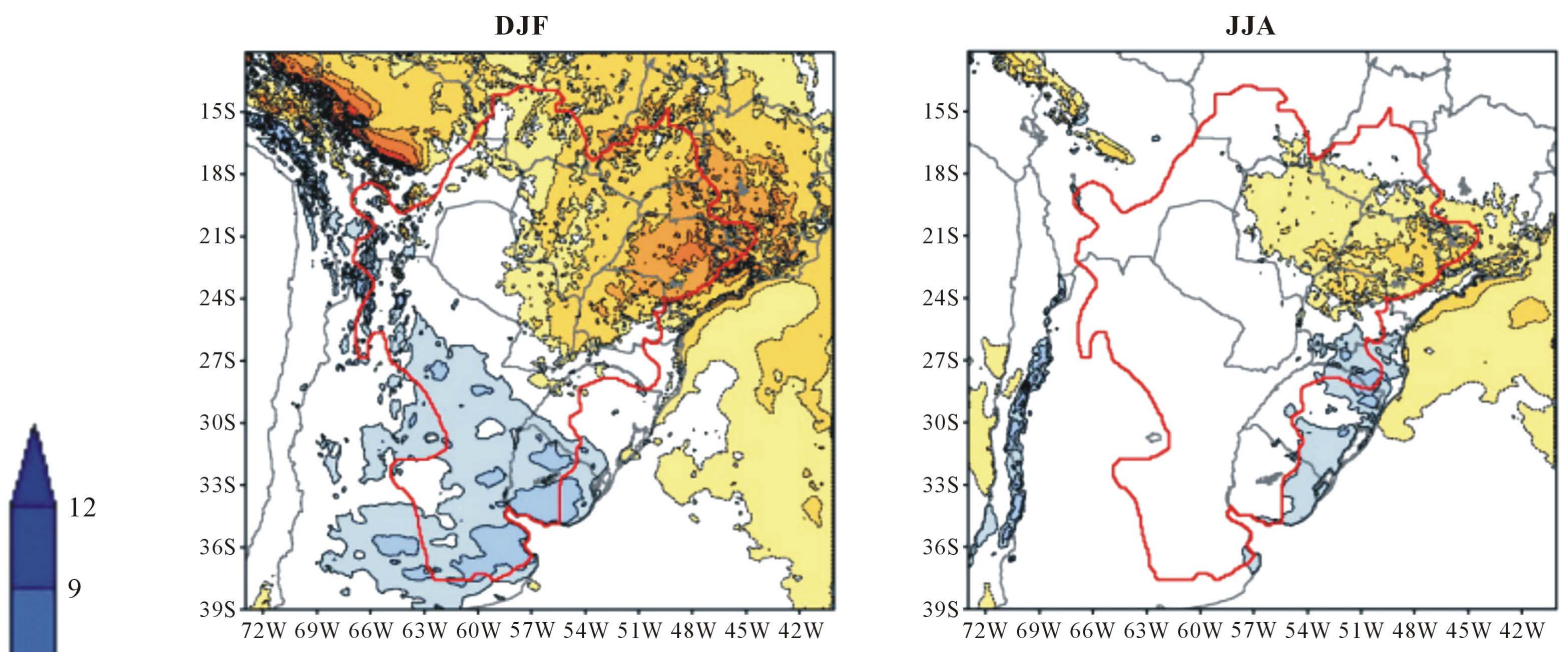

2041-2070
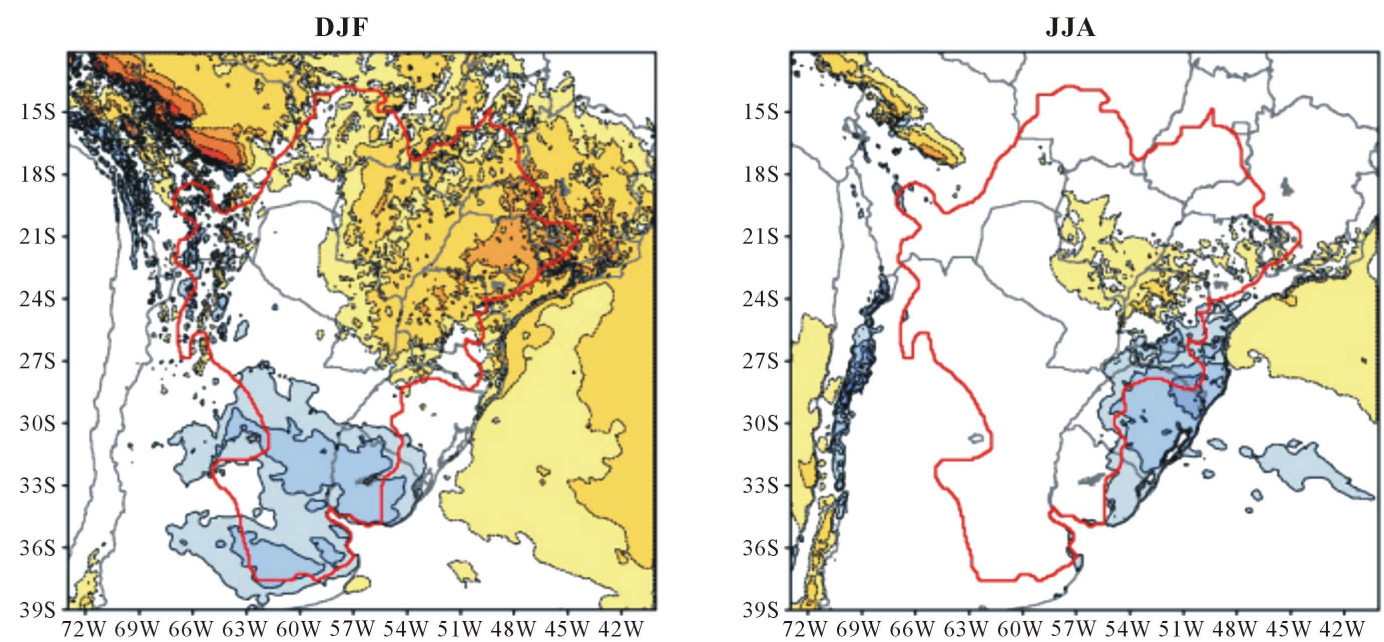

2071-2099
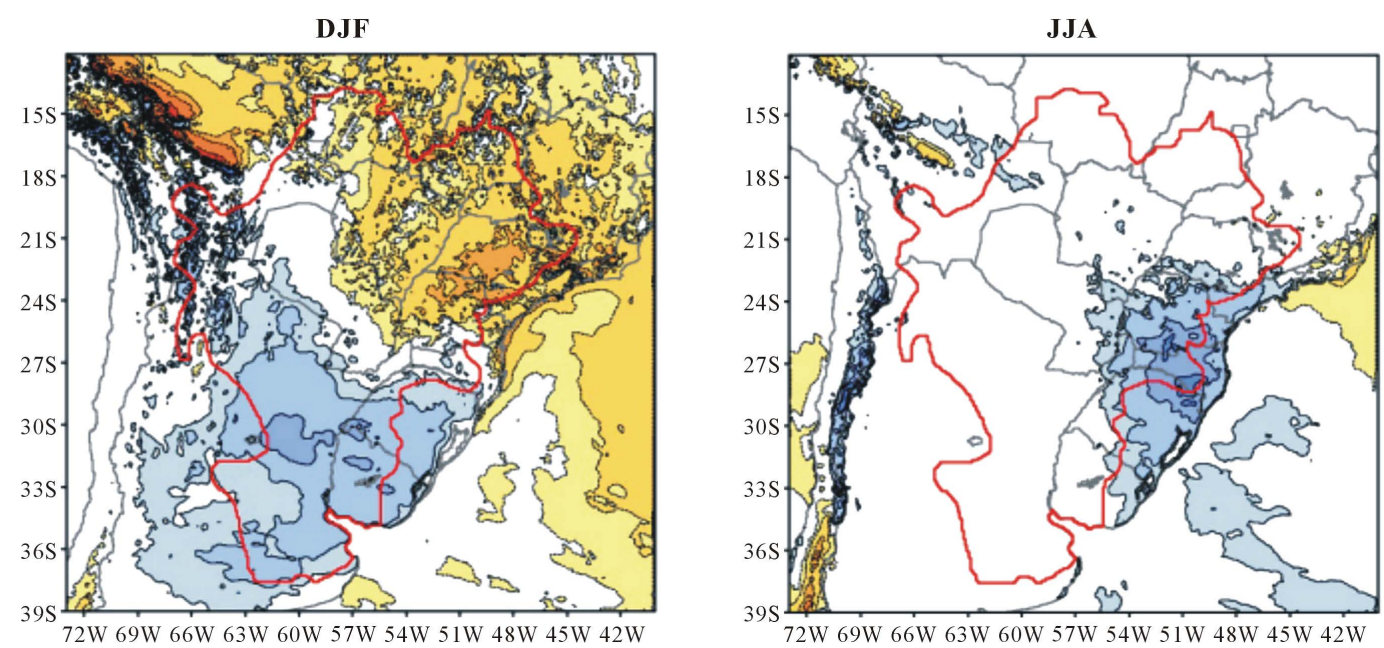

Figure 6. Seasonal mean precipitation anomaly (mm/day), for the periods 2011-2040, 2041-2070 and 2071-2099, in relation to the 1961-1990 period. The La Plata Basin is contoured in red. 
possible to notice that for the 2011-2040 period, it is projected a negative trend in a large portion of the continent, especially in DJF. This negative anomaly extends over the entire region known as the SACZ, from the Atlantic on the coast of the Southeast to the Central-west of Brazil, where the analysis domain ends. This reduction in precipitation is also seen in JJA, but with a lesser magnitude. For the periods of 2041-2070 and 2071-2099, the trend in the SACZ region persists during the summer (DJF), but with a lower intensity. In the assessed periods a trend of increasing precipitation is found in the southern portion of the domain, in particular in Argentina, Uruguay and southern Brazil in DJF and only in the Southern Region of Brazil in JJA.

Average precipitation over the Basin, for the three assessed periods, shows a reduction in precipitation in relation to the present climate (black curve), from December to March. In June, the trend shows increasing precipitation during the 2041-2099 period (Figure 7). During other months, the average signal is not clear, as areas of negative changes are offset by areas with positive changes in precipitation within the basin.

\subsubsection{Temperature}

The differences between the temperatures simulated in the future climate (2011-2040, 2041-2070, and 20712099) and in the present climate (1961-1990) (Figure 8) show an increase in temperature in the entire model domain, in all seasons and periods of years of the century. The areas with largest warming are projected in a band located between $10^{\circ} \mathrm{S}$ and $23^{\circ} \mathrm{S}$ latitude, with an increase in temperature of around $3^{\circ} \mathrm{C}$ in $2011-2040,3.5^{\circ} \mathrm{C}$ in 2041-2070, and $4^{\circ} \mathrm{C}$ in 2071-2099.

The monthly average temperature in the La Plata Basin simulated by the Eta-10 km model version shows a well-defined annual cycle, with lower temperatures during the winter months. For the 2011-2040 timeslice the model shows an increase of up to $2^{\circ} \mathrm{C}$ with respect to the present climate, for 2041-2070 a trend for an increase of up to $3^{\circ} \mathrm{C}$, while for 2071-2099 period the Eta model shows an average increase of up to $3.5^{\circ} \mathrm{C}$ (Figure 9).

\section{Conclusions}

In this work, we evaluated the simulated present climate (1961-1990) and assessed the future climate change projections (2011-2099) generated by the Eta regional climate model, using a spatial resolution of $10 \mathrm{~km}$ with initial and boundary conditions from the Eta-20 km and HadGEM2-ES models, and RCP 4.5 emission scenario.

Results show that the regional model can reproduce the spatial and temporal climatological features of precipitation and temperature in the region of the 1961-1990 period. The positive bias in temperature and negative bias in precipitation, which were commonly, identified in various regional models simulations for the region [18] [20] [33] [36], are substantially reduced in the current simulation for the La Plata Basin. In fact, the current

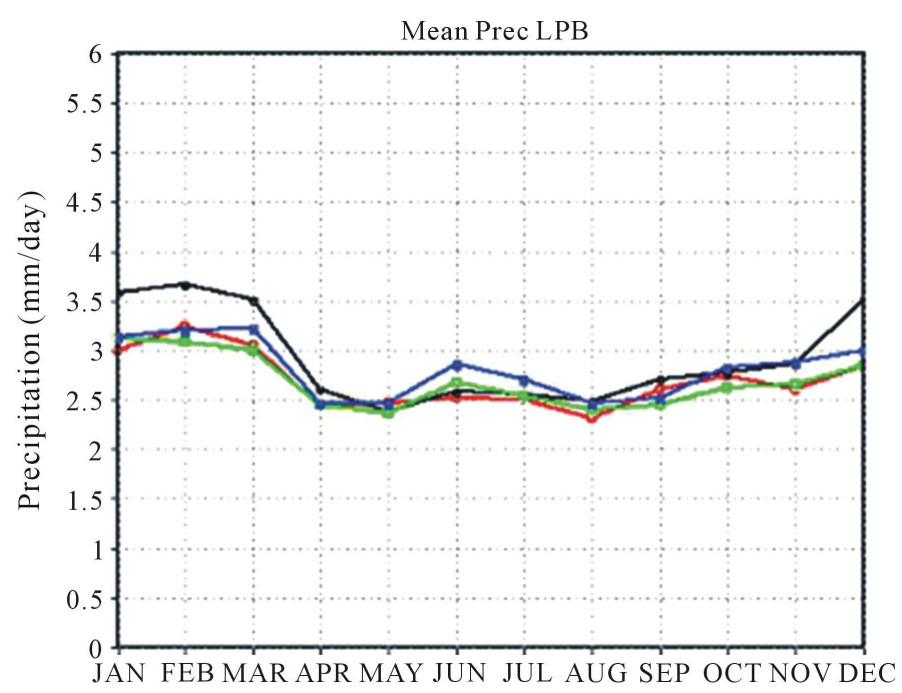

Figure 7. Annual cycle of precipitation (mm/day) in the La Plata Basin (green area sown in Figure 1). The curves represent the present climate 1961-1990 (black) and the timeslices 2011-2040 (red), 20412070 (green) and 2071-2099 (blue). 


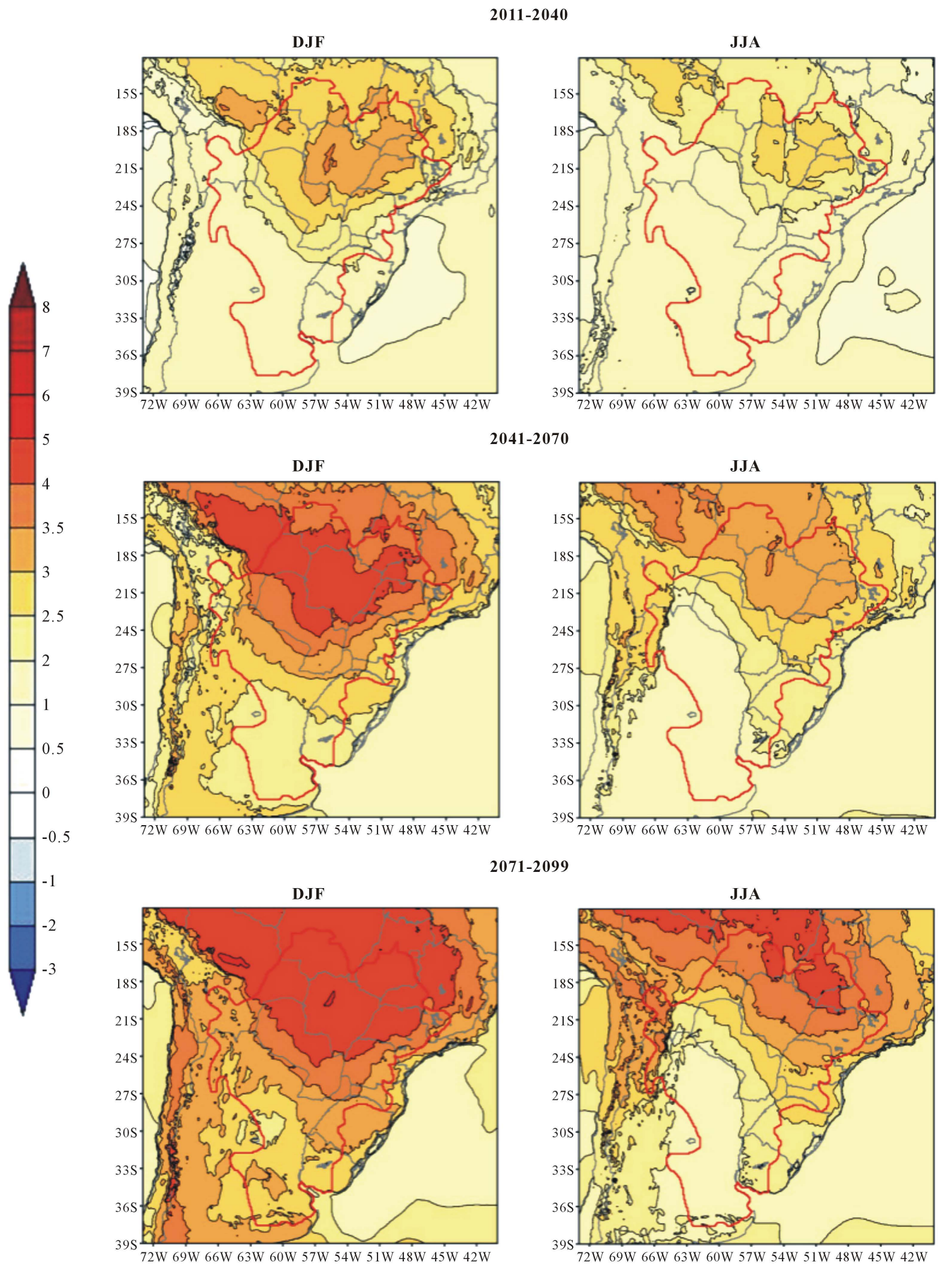

Figure 8. Seasonal mean temperature anomaly $\left({ }^{\circ} \mathrm{C}\right)$, for the periods 2011-2040, 2041-2070 and 2071-2099, compared to the 1961-1990 period. The La Plata Basin is contoured in red. 


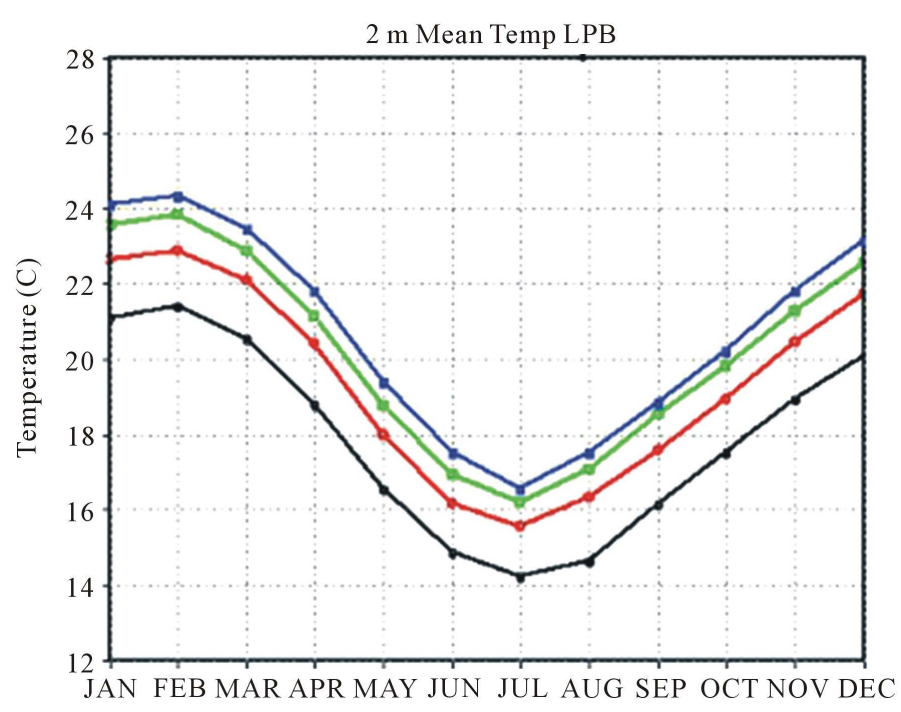

Figure 9. Annual cycle of temperature $\left({ }^{\circ} \mathrm{C}\right)$ in the La Plata Basin (green area shown in Figure 1). The curves represent the present climate 1961-1990 (black) and the timeslices 2011-2040 (red), 20412070 (green) and 2071-2099 (blue).

choice of model domain and setup have performed better than the driver Eta-20km simulations which provided the lateral boundary conditions. Therefore, we conclude that the current model setup is considered adequate for assessment studies of future climate change in the LPB.

In the assessment of future climate change, the simulations showed some changes, in relation to the current climate, in the intensity of some meteorological systems. A trend for a negative change in precipitation is projected over the SACZ region, mainly during the rainy season. This indicates a weakening of the SACZ, due to the intensification of subtropical highs, which may block the passage of frontal systems through the LPB region. From 2041, a trend for an increase in precipitation is projected in southern Brazil and northern Argentina.

In relation to temperature, the projected future climate is warmer over the entire domain, compared to the present climate, with a change reaching $3^{\circ} \mathrm{C}$ in $2011-2040,3.5^{\circ} \mathrm{C}$ in $2041-2070$, and $4^{\circ} \mathrm{C}$ in $2071-2099$. This change is in a band located approximately between the latitudes of $10^{\circ} \mathrm{S}$ and $23^{\circ} \mathrm{S}$.

A good reproducibility of the present climate and the detailed climate projections, with constantly increasing spatial resolution, can provide useful information for impact studies in various socio-economic sectors. As the economy of the LPB is strongly based on agricultural production, further work will be conducted on the assessment of the impacts of climate change on agriculture in this region, and therefore the study presented here is a contribution to studies in this economic sector.

\section{Acknowledgements}

This work was partially funded by the Programa Marco, by CNPq 147816/2010-6 and by CNPq 308035/2013-5.

\section{References}

[1] Marengo, J.A., Jones, R., Alves, L.M. and Valverde, M.C. (2009) Future Change of Temperature and Precipitation Extremes in South America as Derived from the PRECIS Regional Climate Modeling System. International Journal of Climatology, 29, 2241-2255. http://dx.doi.org/10.1002/joc.1863

[2] Christensen, J.H., Krishna Kumar, K., Aldrian, E., An, S.-I., Cavalcanti, I.F.A., de Castro, M., Dong, W., Goswami, P., Hall, A., Kanyanga, J.K., Kitoh, A., Kossin, J., Lau, N.-C., Renwick, J., Stephenson, D.B., Xie, S.-P. and Zhou, T. (2013) Climate Phenomena and Their Relevance for Future Regional Climate Change. In: Stocker, T.F., Qin, D., Plattner, G.-K., Tignor, M., Allen, S.K., Boschung, J., Nauels, A., Xia, Y., Bex, V. and Midgley, P.M., Eds., Climate Change 2013: The Physical Science Basis, Contribution of Working Group I to the Fifth Assessment Report of the Intergovernmental Panel on Climate Change, Cambridge University Press, Cambridge, United Kingdom and New York, 1217-1308. 
[3] Vasconcelos, A.C.F., Schlindwein, S.L., Lana, M.A., Fantini, A.C., Bonatti, M., D’Agostini, L.R. and Martins, S.R. (2014) Land Use Dynamics in Brazilian La Plata Basin and Anthropogenic Climate Change. Climatic Change, 127, 73-81. http://dx.doi.org/10.1007/s10584-014-1081-8

[4] Marengo, J.A., Chou, S.C., Torres, R.R., Giarolla, A., Alves, L.M. and Lyra, A. (2014) Climate Change in Central and South America: Recent Trends, Future Projections, and Impacts on Regional Agriculture. CCAFS Working Paper No. 73, CGIAR Research Program on Climate Change, Agriculture and Food Security (CCAFS), Copenhagen, Denmark. https://www.ccafs.cgiar.org

[5] Pesquero, J.F. (2009) Balanço de umidade na região do sistema de monção da América do Sul em cenários climáticos futuros (2071-2100) utilizando o modelo Eta: um estudo de modelagem. 204 p. (INPE-16602-TDI/1588) Tese (Doutorado em Meteorologia) - Instituto Nacional de Pesquisas Espaciais, São José dos Campos, 2009. http://urlib.net/sid.inpe.br/mtc-m18@80/2009/08.24.18.48

[6] Marengo, J.A., Chou, S.C., Kay, G., Alves, L., Pesquero, J.F., Soares, W.R, Santos, D.C., Lyra, A.A., Sueiro, G., Betts, R., Chagas, D.J., Gomes, J.L., Bustamante, J.F. and Tavares, P. (2012) Development of Regional Future Climate Change Scenarios in South America Using the Eta CPTEC/HadCM3 Climate Change Projections: Climatology and Regional Analyses for the Amazon, São Francisco and the Parana River Basins. Climate Dynamics, 38, 1829-1848. http://dx.doi.org/10.1007/s00382-011-1155-5

[7] Chou, S.C., Lyra, A., Mourão, C., Dereczynski, C., Pilotto, I., Gomes, J., Bustamante, J., Tavares, P., Silva, A., Rodrigues, D., Campos, D., Chagas, D., Sueiro, G., Siqueira, G. and Marengo, J. (2014) Assessment of Climate Change over South America under RCP 4.5 and 8.5 Downscaling Scenarios. American Journal of Climate Change, 3 , 512-527. http://dx.doi.org/10.4236/ajcc.2014.35043

[8] Sánchez, E., Solman, S., Remedio, A.R.C., Berbery, H., Samuelsson, P., Da Rocha, R.P., Mourão, C., Li, L., Marengo, J., de Castro, M. and Jacob, D. (2015) Regional Climate Modelling in CLARIS-LPB: A Concerted Approach towards Twenty First Century Projections of Regional Temperature and Precipitation over South America. Climate Dynamics, 45, 2193-2212. http://dx.doi.org/10.1007/s00382-014-2466-0

[9] Solman, S.A. (2013) Regional Climate Modeling over South America: A Review. Advances in Meteorology, 2013, Article ID: 504357. http://dx.doi.org/10.1155/2013/504357

[10] Thomson, A.M., Calvin, K.V., Smith, S.J., Kyle, G.P., Volke, A., Patel, P., Delgado-Arias, S., Bond-Lamberty, B., Wise, M.A., Clarke, L.E. and Edmonds, J.A. (2011) RCP4.5: A Pathway for Stabilization of Radiative Forcing by 2100. Climatic Change, 109, 77-94. http://dx.doi.org/10.1007/s10584-011-0151-4

[11] New, M., Hulme, M. and Jones, P. (2000) Representing Twentieth-Century Space Time Climate Variability. Part II: Development of 1901-1996 Monthly Grids of Terrestrial Surface Climate. Journal of Climate, 13, 2217-2238. http://dx.doi.org/10.1175/1520-0442(2000)013<2217:RTCSTC>2.0.CO;2

[12] Collins, W.J., Bellouin, N., Doutriaux-Boucher, M., Gedney, N., Halloran, P., Hinton, T., Hughes, J., Jones, C.D., Joshi, M., Liddicoat, S., Martin, G., O’Connor, F., Rae, J., Senior, C., Sitch, S., Totterdell, I., Wiltshire, A. and Woodward, S. (2011) Development and Evaluation of an Earth-System Model-HadGEM2. Geoscientific Model Development, 4, 1051-1075. http://dx.doi.org/10.5194/gmd-4-1051-2011

[13] Cox, P.M. (2001) Description of the TRIFFID Dynamic Global Vegetation Model. Hadley Centre Technical Note 24, Met Office, UK.

[14] Mesinger, F., Janjic, Z.I., Nickovic, S., Gavrilov, D. and Deaven, D.G. (1988) The Step-Mountain Coordinate: Model Description and Performance for Cases of Alpine Lee Cyclogenesis and for a Case of an Appalachian Redevelopment. Monthly Weather Review, 116, 1493-1518. http://dx.doi.org/10.1175/1520-0493(1988)116<1493:TSMCMD>2.0.CO;2

[15] Black, T.L. (1994) The New NMC Mesoscale Eta Model: Description and Forecast Samples. Weather Forecasting, 9, 256-278. http://dx.doi.org/10.1175/1520-0434(1994)009<0265:TNNMEM>2.0.CO;2

[16] Chou, S.C. (1996) Modelo Regional Eta. Climanálise. Volume 1, Especial Edition, Instituto Nacional de Pesquisas Espaciais, São José dos Campos.

[17] Chou, S.C., Fonseca, J.F.B. and Gomes, J.L. (2005) Evaluation of Eta Model Seasonal Precipitation Forecasts over South America Nonlinear Processes. Geophysics, 12, 537-555. http://dx.doi.org/10.5194/npg-12-537-2005

[18] Chou, S.C., Marengo, J.A., Lyra, A., Sueiro, G., Pesquero, J., Alves, L.M., Kay, G., Betts, R., Chagas, D., Gomes, J.L., Bustamante, J. and Tavares, P. (2012) Downscaling of South America Present Climate Driven by 4-Member HadCM3 Runs. Climate Dynamics, 38, 635-653. http://dx.doi.org/10.1007/s00382-011-1002-8

[19] MCT (2010) Second National Communication of Brazil to the United Nations Framework Convention on Climate Change. Ministério da Ciência e Tecnologia, Brasília.

[20] Chou, S.C., Lyra, A., Mourão, C., Dereczynski, C., Pilotto, I., Gomes, J., Bustamante, J., Tavares, P., Silva, A., Rodrigues, D., Campos, D., Chagas, D., Sueiro, G., Siqueira, G., Nobre, P. and Marengo, J. (2014) Evaluation of the Eta Simulations Nested in Three Global Climate Models. American Journal of Climate Change, 3, 438-454. 
http://dx.doi.org/10.4236/ajcc.2014.35039

[21] Fels, S.B. and Schwarzkopf, M.D. (1975) The Simplified Exchange Approximation: A New Method for Radiative Transfer Calculations. Journal of the Atmospheric Sciences, 32, 1475-1488. http://dx.doi.org/10.1175/1520-0469(1975)032<1475:TSEAAN>2.0.CO;2

[22] Lacis, A.A. and Hansen, J.E. (1974) A Parametrization of the Absorption Dissipation in the Atmosphere from LargeScale Balance Requirements. Monthly Weather Review, 49, 608-627.

[23] Betts, A.K. and Miller, M.J. (1986) A New Convective Adjustment Scheme. Part II: Single Column Tests Using GATE Wave, BOMEX and Artic Air-Mass Data Sets. Quarterly Journal Royal Meteorological Society, 112, 693-709. http://dx.doi.org/10.1002/qj.49711247308

[24] Janjić, Z.I. (1994) The Step-Mountain Eta Coordinate Model: Further Developments of the Convection, Viscous Sublayer, and Turbulence Closure Schemes. Monthly Weather Review, 122, 927-945. http://dx.doi.org/10.1175/1520-0493(1994)122<0927:TSMECM>2.0.CO;2

[25] Zhao, Q., Black, T.L. and Baldwin, M.E. (1997) Implementation of the Cloud Prediction Scheme in the Eta Model at NCEP. Weather and Forecasting, 12, 697-712. http://dx.doi.org/10.1175/1520-0434(1997)012<0697:IOTCPS>2.0.CO;2

[26] Ek, M., Mitchell, K.E., Lin, Y., Rogers, E., Grunmann, P., Koren, V., Gayno, G. and Tarpley, J.D. (2003) Implementation of Noah Land Surface Model Advances in the National Centers for Environmental Prediction Operational Mesoscale Eta Model. Journal of Geophysical Research, 108, 8851. http://dx.doi.org/10.1029/2002JD003296

[27] Chen, F., Janjic, Z.I. and Mitchell, K. (1997) Impact of Atmospheric Surface-Layer Parametrization in the New LandSurface Scheme of the NCEP Mesoscale Eta Model. Boundary Layer Meteorology, 85, 391-421. http://dx.doi.org/10.1023/A:1000531001463

[28] IPCC (2013) Summary for Policymakers. In: Stocker, T.F., Qin, D., Plattner, G.-K., Tignor, M., Allen, S.K., Boschung, J., Nauels, A., Xia, Y., Bex, V. and Midgley, P.M., Eds., Climate Change 2013: The Physical Science Basis, Contribution of Working Group I to the Fifth Assessment Report of the Intergovernmental Panel on Climate Change, Cambridge University Press, Cambridge and New York, 1-30. http://dx.doi.org/10.1017/CBO9781107415324.004

[29] IPCC (2000) IPCC Special Report on Emissions Scenarios. Prepared by Working Group III of the Intergovernmental Panel on Climate Change, Cambridge University Press, Cambridge, 570.

[30] Van Vuuren, D.P., Edmonds, J., Kainuma, M.L.T., Riahi, K., Thomson, A., Matsui, T., Hurtt, G., Lamarque, J.-F., Meinshausen, M., Smith, S., Grainer, C., Rose, S., Hibbard, K.A., Nakicenovic, N., Krey, V. and Kram, T. (2011) The Representative Concentration Pathways: An Overview. Climatic Change, 109, 5-31. http://dx.doi.org/10.1007/s10584-011-0148-z

[31] Rao, V.B. and Hada, K. (1990) Characteristics of Rainfall over Brazil: Annual Variations and Connections with Southern Oscillation. Theoretical and Applied Climatology, 42, 81-91. http://dx.doi.org/10.1007/BF00868215

[32] Satyamurty, P., Nobre, C.A. and Dias, P.L.S. (1998) Chapter 3: South America. In: Karoly, D.J. and Vincent, D.G., Eds., Meteorology of the Southern Hemisphere, American Meteorology Society, Boston, 243-282.

[33] Solman, S.A., Sanchez, E., Samuelsson, P., et al. (2013) Evaluation of an Ensemble of Regional Climate Model Simulations over South America Driven by the ERA-Interim Reanalysis: Model Performance and Uncertainties. Climate Dynamics, 41, 1139-1157. http://dx.doi.org/10.1007/s00382-013-1667-2

[34] Oliveira, A. (1986) Interações entre sistemas frontais na América do Sul e a convecção da Amazônia. (INPE-4008TDL/239). Thesis, Instituto Nacional de Pesquisas Espaciais, São José dos Campos, SP, 115 p.

[35] Urrutia, R. and Vuille, M. (2009) Climate Change Projections for the Tropical Andes Using a Regional Climate Model: Temperature and Precipitation Simulations for the End of the 21st Century. Journal of Geophysical Research, 114, Article ID: D02108. http://dx.doi.org/10.1029/2008JD011021

[36] Lange, S., Rockel, B., Volkholz, J. and Bookhagen, B. (2015) Regional Climate Model Sensitivities to Parametrizations of Convection and Non-Precipitating Subgrid-Scale Clouds over South America. Climate Dynamics, 44, 28392857. http://dx.doi.org/10.1007/s00382-014-2199-0 